\title{
$\mathrm{LOCA}$ 이후 원자로건물집수조 여과기의 수두손실에 대한 화학적 영향의 실험연구
}

구희권 ${ }^{1}$, 정범영 ${ }^{1}$, 홍광 $^{1}$, 정은선 $^{1}$, 정현준 $^{1}$, 박병기 $^{1^{*}}$, 이인형 $^{1}$, 박종운 $^{2}$ ${ }^{1}$ 순천향대학교 에너지환경공학과, ${ }^{2}$ 한국수력원자력주식회사

\section{Experimental Study of Chemical Effects on Head Loss across Containment Sump Strainer under Post-LOCA Environment}

\author{
Hee Kwan Kuํ. Bum Young Jung ${ }^{1}$, Kwang Hong ${ }^{1}$, Eun Sun Jung \\ Hyun Jun Jeong ${ }^{1}$, Byung Gi Park ${ }^{1^{*}}$, In Hyoung Rhee ${ }^{1}$ and Jong Woon Park ${ }^{2}$ \\ ${ }^{1}$ Department of Energy \& Environmental Engineering, Soonchunhyang University \\ ${ }^{2}$ Korea Hydro and Nuclear Power Co. Ltd.
}

\begin{abstract}
요 약 원자력발전소에서 냉각재상실사고이후 원자로건물집수조 여과기에서 화학적 영향에 의한 수두손실 변화를 관찰하기 위하여 시험장치에서 단기살수조건, 장기살수조건, 및 화학적 영향을 주는 물질이 없는 조건에 대해 30 일 동안 종합적인 수두손실 시험을 수행하였다. 시험결과는 수두손실이 살수조건에 따라 노출된 화학적 영향을 주는 물 질의 양에 크게 의존함을 보였다. 시험종료후 수거된 침전물의 XRD 분석은 침전물이 주로 인산화합물임을 보였다. 수두손실과 용해된 화학종의 비교결과는 화학적 영향을 주는 물질 중에서 $\mathrm{Al}$ 과 $\mathrm{Zn}$ 의 부식이 시험 초기에 높은 수두 손실 증가율의 원인이 됨을 보였다. 금속 시편에 부동피막이 형성된 이후에 수두손실 증가율은 감소하지만 지속적으 로 수두손실이 증가하는 현상은 NUKON 및 콘크리트에서 침출반응에 의해 발생하는 $\mathrm{Si}, \mathrm{Mg}$, 및 $\mathrm{Ca}$ 이 침전물을 형성 하는 반응에 기인함을 보였다.
\end{abstract}

\begin{abstract}
An integral head loss test in a test apparatus was conducted to simulate chemical effects on a head loss across a strainer in a pressurized water reactor (PWR) containment water pool after a loss of coolant accident (LOCA). The test was conducted during 30 days in the condition of a short spray, a long spray, and no materials with chemical effects. The result exhibited that the head loss was affected on amounts of the exposed materials according to spray conditions. XRD analysis of the collected precipitates showed that the precipitates were phosphate compounds. Comparison of the head loss with dissolved species concentration showed that high increase rate of the head loss resulted from the corrosion of aluminum and zinc but slow increase rate of the head loss resulted from the precipitates induced by $\mathrm{Si}, \mathrm{Mg}$, and $\mathrm{Ca}$ from leaching reaction at NUKON and concrete after passivation of metal specimens.
\end{abstract}

Key Words : Head Loss, Chemical Effects, Strainer, LOCA, Nuclear Power Plant

\section{1. 서론}

원자력발전소는 설계기준 가상사고인 냉각재상실사고 (LOCA, Loss of Coolant Accident)의 발생 후에 비상노심 냉각계통(ECCS, Emergency Core Cooling System)이 가 동하여 노심을 냉각시킴으로써 안전성을 보장한다. 그러
나 LOCA에 의해 발생되는 파손된 이물질 및 화학반응에 의해 생성되는 화학적부산물이 원자로건물집수조 여과기 에 축적되어 수두손실을 증가시킴으로서 $\mathrm{ECCS}$ 의 냉각성 능을 저하시킬 가능성이 있다.[1,2]

원자로건물집수조에서 파손된 이물질에 의한 수두손 실은 ECCS 운전시작과 함께 나타나지만 화학적 부산물

*교신저자 : 박병기(byunggi@sch.ac.kr)

접수일 09년 08월 28일 수정일 09년 12월 08일 게재확정일 09년 12월 16일 
의 침전은 $\mathrm{LOCA}$ 이후 $\mathrm{ECCS}$ 의 운전시간인 30 일 동안 지 속적으로 수두손실에 화학적 영향을 준다. 원자로건물집 수조에서 물의 $\mathrm{pH}$, 온도, 용해된 화학종의 종류 및 양 등 과 같은 화학적 조건에 의해서 시간에 따라 1) 물질의 부 식 및 침출, 2) 새로운 화합물 또는 침전물 생성, 3) 형성 된 화합물 및 침전물의 여과기 이동 및 축적되는 일련의 과정을 거쳐 수두손실에 영향을 준다. LOCA이후 ECCS 에 의한 30 일 동안의 재순환운전에서 생성되어 수두손실 에 영향을 줄 가능성이 높은 대표적인 침전물은 $\mathrm{AlOOH}$, $\mathrm{NaAlSiO}_{4}, \mathrm{Ca}_{3}\left(\mathrm{PO}_{4}\right)_{2}$ 등으로 알려져 있지만[3] 원자로건 물 내부의 환경이 발전소 고유특성을 가지기 때문에 각 발전소에서 발생가능한 화학적부산물에 차이가 있다. 따 라서 안전성 보장을 위한 여과기 성능개선을 위해서는 각 발전소의 고유특성을 반영하고 화학적 영향을 고려하 여 종합적으로 수두손실을 평가하여야 한다.

본 연구에서는 고리 1 호기 원자로건물 특성을 반영하 여 화학적 영향을 고려한 수두손실 변화를 30 일 동안 측 정하여 수두손실 증가에 기여하는 화학적 영향을 평가하 였다.

\section{2. 실험방법}

원자로건물에서 LOCA이후 여과기에 축적된 이물질 층에서 화학적 영향을 고려한 수두손실을 평가하기 위한 시험장치는 수두손실 측정부, 여과기, 수조, 펌프, 전열기, 및 수화학 환경 측정함으로 구성된다. 시험장치는 다양한 $\mathrm{pH}$ 에서 구성 재료가 부식되어 화학적 영향을 주지 않도 록 스테인리스강으로 제작하였으며 수조에 설치되는 시 편 사이에서 갈바닉 부식이 발생하지 않도록 충분한 공 간을 두었다. 시험장치는 30 일 동안 수화학 환경조건을 방해하지 않도록 자료취득시스템을 자동화하여 수두손 실, 유량, 물 온도, $\mathrm{pH}$ 를 온라인으로 측정할 수 있도록 하 였으며 정전에 대비하여 무정전전원장비를 갖추었다.[4]

화학적 영향 평가의 보수성을 보장하기 위하여 원자로 건물 수조의 물 부피는 고리 1 호기 ECCS 재순환집수조 성능평가에 따라 최대 물 부피인 $37,917 \mathrm{ft}^{3}$ 을 적용하였 다.[5] 성능평가에 따라 요구되는 여과기 면적 2,200 $\mathrm{ft}^{2}$ 을 기준으로 고리 1 호기 $\mathrm{ECCS}$ 의 주요 운전인자로부터 시험 장치의 시험조건을 설정하였다. 시험조건으로 여과기로 의 평균 접근속도와 여과기 표면적 대 물 부피비를 고리 1 호기와 동일하게 설정하고 종합적 수두손실 시험을 위 한 물 부피 및 유량을 결정하여 표 1 에 정리하였다.
[표 1] 고리1호기 시험을 위한 유동 조건

\begin{tabular}{|c|c|c|c|}
\hline 변 수 & 고리1호기 & 시험장치 & 축소비 \\
\hline 평균접근속도 & \multicolumn{2}{|c|}{$0.2256 \mathrm{~cm} / \mathrm{s}$} & $1: 1$ \\
\hline 여과기 면적 & $2,043,867 \mathrm{~cm}^{2}$ & $78.54 \mathrm{~cm}^{2}$ & $1: 3.84 \mathrm{E}-5$ \\
\hline $\begin{array}{c}|c| \\
\text { 여과기ㅁㅕㅕㄴ적 대 } \\
\text { 물부피 비 }\end{array}$ & $0.002 \mathrm{~cm}^{-1}$ & $1: 1$ \\
\hline 물 부피 & $1,073,689,872 \mathrm{~cm}^{3}$ & $41,239 \mathrm{~cm}^{3}$ & $1: 3.84 \mathrm{E}-5$ \\
\hline 유량 & $27,6091 \mathrm{pm}$ & $1.06 \mathrm{lpm}$ & $1: 3.84 \mathrm{E}-5$ \\
\hline
\end{tabular}

$\mathrm{ECCS}$ 에 의한 재순환운전 동안 화학적부산물의 발생 에 영향을 주는 주된 인자는 $\mathrm{pH}$ 와 온도이다. $\mathrm{ECCS}$ 의 재 순환운전 동안 $\mathrm{pH}$ 를 정확하게 평가할 수 없기 때문에 LOCA이후 원자로건물집수조에서 $\mathrm{pH}$ 에 영향을 주는 화 학물질인, 붕산, $\mathrm{LiOH}$, 염산에 대해 보수적으로 평가된 농도를 시험에 사용하였으며 표 2와 같다.[4] 시험장치에 서 온도변화는 원자로냉각재계통 29인치 고온관 양단파 단의 경우에 디젤발전기 단일고장을 가정한 사고시나리 오에 따라 계산된 결과를 사용하였다.[5]

원자로건물집수조 환경에서 수두손실을 발생시키는 이물질은 $\mathrm{NUKON}$, 도장재의 파편, 및 잠복이물질과 알 루미늄, 아연, 콘크리트 등에서 발생한 화학적 부산물 등 이다. 성능평가[5]에서 LOCA이후 발생하여 여과기 표면 에 쌓이는 이물질 양을 추정한 결과와 수두손실에 화학 적 영향을 주는 물질의 양을 추정한 결과는 표 3 에 나타 내었다. 원자로건물집수조 환경에서 발생하는 수두손실 과 유사성을 가지도록 여과기면적 대 물부피 비인 3.84 $\times 10^{-5}$ 을 사용하여 수두손실을 발생시키는 물질의 양을 평 가하였으며[4] 표 2에 나타내었다.

시험에서 원자로건물집수조와 같은 동일한 화학적 영 향을 주도록 ICET의 시험준비 절차[3]에 준하여 알루미 늄으로 $\mathrm{A} 1050$, 아연으로 아연철판, 콘크리트로 $\mathrm{KSL}$ 5105 표준[6]에 따라 제작된 시편을 사용하였다. 물질의 양은 원자로건물집수조 수위에 따라 침수된 양과 침수안 된 양으로 구분하여 산정하고 여과기면적 대 물부피 비 를 사용하여 시험에 사용할 양을 평가하였으며 표 2에 주 어진 바와 같다. 또한 원자로건물집수조 $\mathrm{pH}$ 에서 시험을 수행하기 위하여 $\mathrm{pH}$ 에 영향을 주는 화학물질의 농도를 원자로건물집수조에서의 농도와 같은 값을 사용하였다.

[표 2] 고리 1 호기 시험에 필요한 물질 양

\begin{tabular}{|l|r|rr|}
\hline \multicolumn{1}{|c|}{ 이물질 종류 } & 고리1호기 & 시험장치 \\
\hline \hline \multicolumn{4}{|l|}{ 여과기 표면에 쌓인 이물질 } \\
\hline NUKON $^{\mathrm{TM}}$ & $376.2 \mathrm{ft}^{3}$ & 15.726 & $\mathrm{~g}$ \\
\hline 입자형 도장재 이물질 & $763.1 \mathrm{lbm}$ & 13.292 & $\mathrm{~g}$ \\
\hline 조각형 도장재 이물질 & $826.7 \mathrm{lbm}$ & 14.399 & $\mathrm{~g}$ \\
\hline
\end{tabular}




\begin{tabular}{|c|c|c|c|c|}
\hline \multicolumn{2}{|c|}{ 잠복이물질 - 입자형 } & & $255 \mathrm{lbm}$ & $4.442 \mathrm{~g}$ \\
\hline \multicolumn{5}{|c|}{ 원자로건물에 위치하여 화학적 영향을 주는 물질 } \\
\hline \multicolumn{2}{|l|}{ NUKON } & \multicolumn{2}{|c|}{$681.12 \mathrm{lbm}$} & \multirow{2}{*}{$\begin{array}{r}11.86 \mathrm{~g} \\
9.56 \mathrm{~cm}^{2}\end{array}$} \\
\hline \multirow{2}{*}{ 알루미늄 } & 침수된 & \multicolumn{2}{|r|}{$268 \mathrm{ft}^{2}$} & \\
\hline & 침수안된 & \multicolumn{2}{|c|}{$7,034 \mathrm{ft}^{2}$} & $280.55 \mathrm{~cm}^{2}$ \\
\hline \multirow{2}{*}{ 아연 } & 침수된 & \multicolumn{2}{|r|}{$4,540 \mathrm{ft}^{2}$} & $161.96 \mathrm{~cm}^{2}$ \\
\hline & 침수안된 & \multicolumn{2}{|c|}{$119,063 \mathrm{ft}^{2}$} & $4247.54 \mathrm{~cm}^{2}$ \\
\hline 콘크리트 & 침수된 & \multicolumn{2}{|c|}{$14,262 \mathrm{ft}^{2}$} & $508.79 \mathrm{~cm}^{2}$ \\
\hline \multicolumn{5}{|c|}{ p pH에 영향을 주는 화학물질의 농도 } \\
\hline \multirow{2}{*}{\multicolumn{2}{|c|}{ Boron (ppm) }} & 최대 & 최소 & \multirow{2}{*}{2,756} \\
\hline & & 1,247 & 2,756 & \\
\hline \multicolumn{2}{|c|}{ Lihium (ppm) } & 0.013 & 0.550 & 0.7 \\
\hline \multicolumn{2}{|c|}{$\mathrm{TSP}\left(\mathrm{Na}_{3} \mathrm{PO}_{4}\right)(\mathrm{mg} / \mathrm{l})$} & \multicolumn{2}{|c|}{1,233} & 1,233 \\
\hline $\mathrm{HCl}(\mathrm{ppn}$ & & \multicolumn{2}{|c|}{-} & 100 \\
\hline
\end{tabular}

여과기 위에 NUKON, 입자형 및 조각형 도장재 이물 질, 잠복이물질이 시험장치 여과기 표면으로 자연적으로 침강하여 형성되도록 한 후 붕산과 $\mathrm{LiOH}$ 및 염산을 주입 한다. 온도조건을 설정한 후 마지막으로 $\mathrm{TSP}$ 를 넣고 시 험을 시작하였다. 시험은 표 3에 주어진 바와 같이 화학 적 영향에 대한 살수효과를 평가하기 위하여 Test 1 은 단 기살수조건, Test 2 는 장기살수조건으로 설정하였으며 Test 3 은 화학적 영향을 주는 물질 및 $\mathrm{pH}$ 를 결정하는 화 학물질이 없는 경우와 화학적 영향이 있는 경우를 비교 하기 위하여 수행하였다.

[표 3] 화학적 영향을 고려한 수두손실 시험조건

\begin{tabular}{|c|c|c|c|}
\hline & Test 1 & Test 2 & Test 3 \\
\hline $\begin{array}{l}\text { 파손된 } \\
\text { 이물질 }\end{array}$ & \multicolumn{3}{|c|}{$\begin{array}{l}\text { NUKON, 입자형 및 조각형 도장재 } \\
\text { 대용품, 잠복이물질 }\end{array}$} \\
\hline $\begin{array}{l}\text { 화학적 영향 } \\
\text { 물질 }\end{array}$ & \multicolumn{2}{|c|}{ 알루미늄, 아연, 콘크리트 } & N.A. \\
\hline $\begin{array}{l}\mathrm{pH} \text { 결정 } \\
\text { 화학물질 }\end{array}$ & \multicolumn{2}{|c|}{$\mathrm{H}_{3} \mathrm{BO}_{3}, \mathrm{LiOH}, \mathrm{HCl}, \mathrm{TSP}$} & N.A. \\
\hline 온도 & $\begin{array}{l}\text { 단기살수조 } \\
\text { 건 }\end{array}$ & $\begin{array}{l}\text { 장기살수조 } \\
\text { 건 }\end{array}$ & $\begin{array}{l}\text { 단기살수조 } \\
\text { 건 }\end{array}$ \\
\hline 유량 & $1.06 \mathrm{lpm}$ & $1.06 \mathrm{lpm}$ & $1.06 \mathrm{lpm}$ \\
\hline 시험시간 & \multicolumn{3}{|c|}{ 30일 } \\
\hline
\end{tabular}

\section{3. 실험결과}

단기살수조건인 Test 1 은 살수가 운전원 조작에 의해 재순환운전이 시작된 후 1 시간 후에 중지된다는 가정에
따라 수행되었으며 살수에 노출되었다고 가정한 시편은 시험 시작 1 시간 후에 시험장치에서 제거하였다. 그림 2 에 보인 바와 같이 시험이 진행됨에 따라 96 시간까지 $0.31 \mathrm{kPa}$ 까지 수두손실이 증가하였다. 시험시작후 약 250 시간에 시험장치가 정지되고 305 시간에 시험이 다시 시 작된 후 수두손실은 $0.24 \mathrm{kPa}$ 에서 점차 증가하여 0.26 $\mathrm{kPa}$ 에 도달하였다. 장기살수조건인 Test 2 는 살수가 재순 환 운전동안 지속된다는 가정에 따라 시험을 수행되었다. 그림 3에 보여준 바와 같이 수두손실은 재순환운전 시작 후 약 200 시간까지 $2 \mathrm{kPa}$ 에 도달한 후 이후 서서히 증가 하여 재순환 운전 종료 시점인 720시간에서는 $3.6 \mathrm{kPa}$ 의 값을 보였다. 화학적 영향을 주는 물질이 없는 경우인 Test 3 에서 그림 4 에 보인 바와 같이 온도가 $90^{\circ} \mathrm{C}$ 에서 4 $5^{\circ} \mathrm{C}$ 까지 감소하는 동안 수두손실은 약 $0.02 \mathrm{kPa}$ 에서 0.04 $\mathrm{kPa}$ 까지 증가하고 이후 서서히 증가하여 $0.06 \mathrm{kPa}$ 에 도 달하였다. Test 3에서 온도가 감소하는 동안 수두손실은 약 $0.02 \mathrm{kPa}$ 만큼 증가하였으며 이는 온도변화에 따른 물 의 점성증가에 기인한 결과이다.

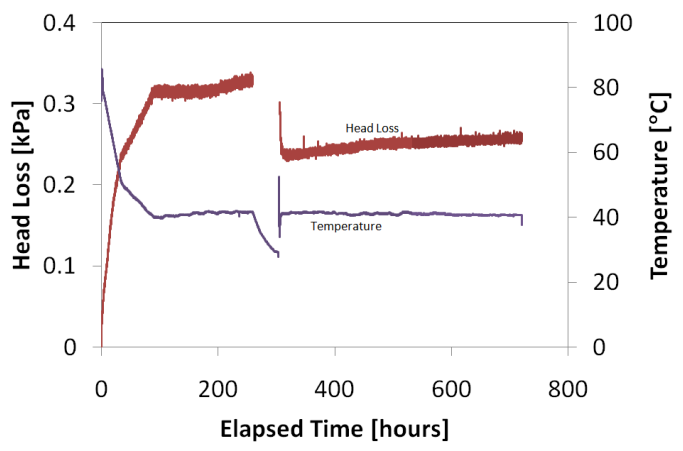

[그림 1] Test 1의 온도와 수두손실 변화

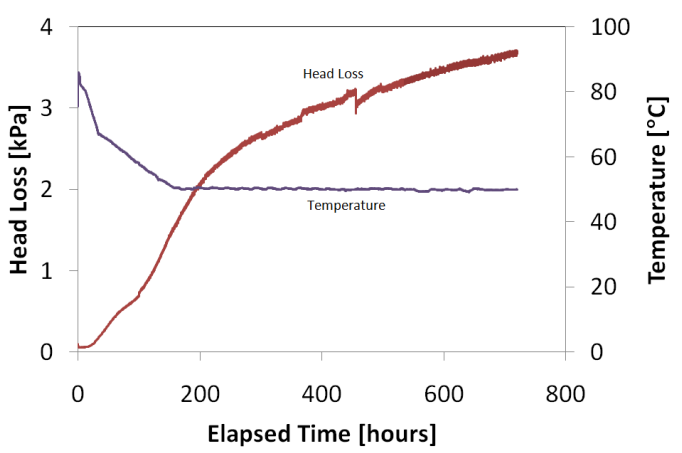

[그림 2] Test 2의 온도와 수두손실 변화 


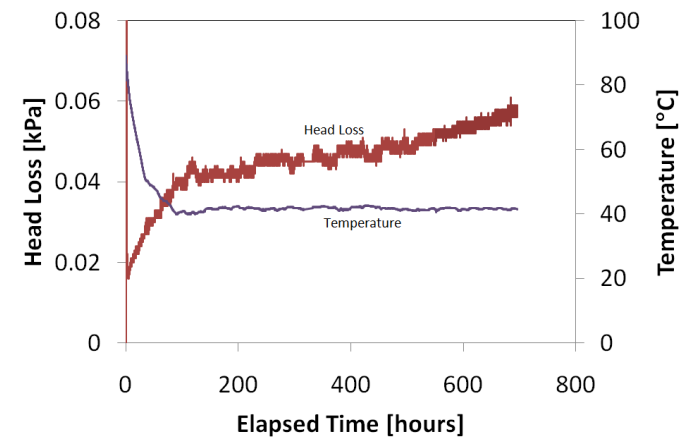

[그림 3] Test 3의 온도와 수두손실 변화

시험에서 24시간을 주기로 Test 1과 Test 2에서 시료 를 채취하여 ICP-AES로 $\mathrm{Al}, \mathrm{Zn}, \mathrm{Mg}, \mathrm{Ca}, \mathrm{Si}, \mathrm{Fe}$ 성분의 농도 분석을 수행하였다. ICP-AES 분석에서 시료의 전처 리 전후에 대해 분석하였으며 전처리 전 시료분석은 분 석 대상이 용해된 농도를 나타내며 전처리 후의 분석결 과는 입자 형태를 포함하는 총 농도를 나타낸다. 시험동 안 Test 1과 Test 2에서 $\mathrm{Al}, \mathrm{Zn}, \mathrm{Fe}, \mathrm{Ca}, \mathrm{Mg}, \mathrm{Si}$ 의 총 농도 변화는 각각 그림 $4(\mathrm{a})$ 와 (b)와 같다.
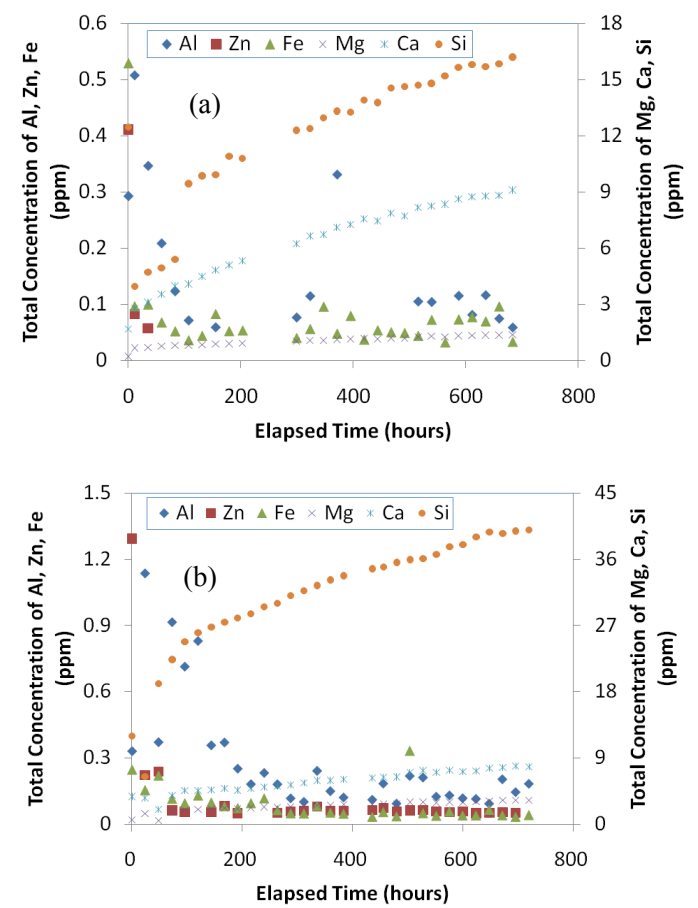

[그림 4] 용액에서 $\mathrm{Al}, \mathrm{Zn}, \mathrm{Fe}, \mathrm{Mg}, \mathrm{Ca}, \mathrm{Si}$ 의 농도 변화 (a) Test 1 (b) Test 2

그림 4(a)와 (b)에서 볼 수 있는 바와 같이 Test 1과
Test 2 모두 부식에 의해 생성되는 $\mathrm{Al}, \mathrm{Zn}, \mathrm{Fe}$ 의 총 농도 는 수두손실 증가율이 높은 구간에서 농도가 감소하는 경향을 보이며 이후 안정화된다. 그러나 침출반응에 의해 생성되는 $\mathrm{Si}, \mathrm{Ca}, \mathrm{Mg}$ 은 지속적으로 증가하는 경향을 보 이며 이러한 경향은 수두손실 증가율이 낮은 구간에서 수두손실 증가의 원인이 된다고 볼 수 있다.

Test 1과 Test 2에서 $\mathrm{Al}$ 의 농도는 시험 시작 후 24시간 동안 증가하다가 이후 감소하여 Test 1은 약 100 시간 Test 2 는 약 250 시간부터 안정화 된다. $\mathrm{Al}$ 의 총 농도가 안정화된 이후에는 전처리전에 $\mathrm{Al}$ 이 관찰되지 않는 것으 로 보아 이 시간 이후에는 대부분의 알루미늄은 입자 형 태로 존재한다고 볼 수 있다. $\mathrm{Zn}$ 의 경우는 시험 초기의 농도가 가장 높으며 이후 빠르게 감소하여 Test 1에서는 48 시간 이후에는 관찰되지 않지만 Test 2 에서는 73 시간 경과 후에도 전처리 후의 분석에서 $0.06 \mathrm{ppm}$ 으로 측정되 었다. 이러한 결과는 $\mathrm{Al}, \mathrm{Zn}$ 시편의 표면에 부동피막이 형성되어 부식율의 감소에 기인한 것으로 판단되며 Test 1 과 Test 2 에서 시간의 차이는 시편 양의 영향으로 볼 수 있다. 수두손실 측정 결과와 비교하면 $\mathrm{Al}$ 과 $\mathrm{Zn}$ 의 총농도 가 수두손실 증가율과 밀접하게 연관되어 있음을 알 수 있다.

Test 1과 Test 2에서 $\mathrm{Ca}, \mathrm{Mg}$, 및 $\mathrm{Si}$ 의 총 농도는 시간 이 경과함에 따라 지속적으로 증가하는 경향을 보인다. 이 원소들은 $\mathrm{NUKON}$ 과 콘크리트에서 침출반응으로 발 생하여 인산이온과 반응하여 수두손실에 영향을 줄 것이 다. $\mathrm{Mg}$ 는 $\mathrm{Si}$ 이나 $\mathrm{Ca}$ 에 비해 상대적으로 낮은 농도를 보 였으며 시험 초기에 급격히 증가하고 이후 낮은 증가율 을 보인다. 이러한 농도 증가는 수두손실 증가율이 상대 적으로 낮은 구간에서 수두손실 증가의 원인이 된다고 볼 수 있다.

화학적 영향 시험을 종료하고 물을 배수한 후 시험장 치 수조 바닥에는 콜로이드 형상의 침전물이, 금속시편에 는 흰색 침전물이 관찰되었다. 관찰된 침전물의 성분을 분석하기 위하여 XRD 분석을 수행하였으며 분석 결과를 표 4에 정리하였다.

[표 4] 시험장치에서 수거한 침전물의 XRD 분석결과 (1: 수조바닥 균일 침전물, 2 : 수조바닥 침전물 덩어리, 3: 금속시편 표면 침전물 덩어리)

\begin{tabular}{|c|c|c|c|c|c|c|}
\hline & \multicolumn{3}{|c|}{ Test 1} & \multicolumn{3}{|c|}{ Test 2} \\
\hline & 1 & 2 & 3 & 1 & 2 & 3 \\
\hline $\mathrm{SiO}_{2}$ & O & O & 0 & & 0 & 0 \\
\hline $\mathrm{Zn}_{3}\left(\mathrm{PO}_{4}\right)_{2}$ & 0 & & 0 & 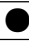 & 0 & 0 \\
\hline $\mathrm{Mn}_{3} \mathrm{Zn}\left(\mathrm{PO}_{4}\right)_{2} \cdot \mathrm{H}_{2} \mathrm{O}$ & 0 & & 0 & ? & & 0 \\
\hline $\mathrm{AlPO}_{4}$ & & O & & O & & \\
\hline $\mathrm{AlH}_{3}$ & & & 0 & & & \\
\hline
\end{tabular}


시험종료후 수조 바닥에 생성된 균일한 침전물은 주로 $\mathrm{SiO}_{2}$ 와 $\mathrm{Zn}_{3}\left(\mathrm{PO}_{4}\right)_{2}$ 이며 Test 1 의 경우 추가로 $\mathrm{Mn}_{3} \mathrm{Zn}\left(\mathrm{PO}_{4}\right)$ ${ }_{2} \cdot \mathrm{H}_{2} \mathrm{O}$ 가 관찰되었다. 인산아연은 아연 시편의 부식에 의해 발생된 아연 이온과 TSP에 의해 생성된 인산 이온 이 반응하여 형성된 침전물로 알루미늄에 비해 상대적으 로 많은 아연 양에 의해 주 침전물로 형성된 것으로 추정 된다. 화학적 영향을 가장 많이 주는 것으로 알려진 알루 미늄의 경우 수조 바닥에서 발견된 침전물 덩어리에서 인산알루미늄 형태로 발견되었다.

Test 1과 Test 2에서 시험종료후 $\mathrm{Al}$ 시편을 회수하여 SEM-EDS를 사용하여 표면분석을 수행하였다. 그림 5(a) 와 (b)에 보여준 바와 같이 $\mathrm{P}, \mathrm{Ca}, \mathrm{Na}, \mathrm{O}$ 등이 $\mathrm{Al}$ 표면에 존재하며 $\mathrm{P}$ 는 인산이온에 기인한 것으로 $\mathrm{Al}$ 과 반응하여 표면에 피막을 형성하였다고 볼 수 있다.
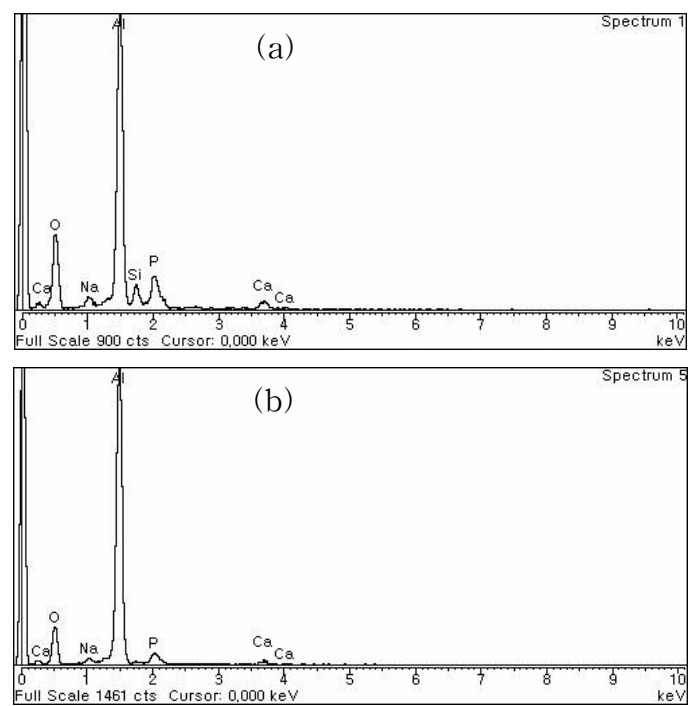

[그림 5] $\mathrm{Al}$ 시편에 대한 SEM-EDS 분석 결과 (a) Test 1 (b) Test 2

이러한 결과로부터 Test 1 과 Test 2 에서 물의 점성증 가 효과에 비해 상대적으로 높은 수두손실 증가율은 $\mathrm{Al}$ 과 $\mathrm{Zn}$ 의 부식에 의해 생성된 화학적부산물에 기인한 것 으로 볼 수 있다. 그림 4(a)와 (b)의 $\mathrm{Al}$ 과 $\mathrm{Zn}$ 의 총농도 변 화와 수두손실 증가율은 유사한 변화를 보인다. 수두손실 증가율 감소는 금속 시편의 표면에 부동피막이 형성되어 부식율이 감소함에 따라 화학적부산물의 생성량도 감소 하여 수두손실 증가율이 감소한 것으로 판단된다. Test 1 과 Test 2에서 수두손실 증가율의 차이는 살수조건에 따 라 물에 노출된 표면적이 알루미늄의 경우 29 배, 아연의 경우 27 배 차이가 나기 때문에 발생한 것으로 볼 수 있 다.
부식에 의해 발생되는 $\mathrm{Al}$ 과 $\mathrm{Zn}$ 와 같은 화학종의 농도 는 TSP의 영향에 의한 부동피막 형성으로 감소하지만 $\mathrm{NUKON}$ 및 콘크리트 등에서 침출되는 $\mathrm{Si}, \mathrm{Ca}, \mathrm{Mg}$ 의 농 도는 계속 증가하여 수두손실에 영향을 준다. 그러나 침 출 반응에 의해 발생되는 화학종은 상대적으로 화학적부 산물을 적게 발생시켜 수두손실이 서서히 증가된다고 볼 수 있다. 이러한 현상은 화학적 영향을 주는 물질이 없는 경우에 수두손실을 측정한 Test 3 의 시험결과에서도 확 인 할 수 있다. 즉 온도가 일정하게 유지되고 있는 동안 장기간 물에 노출된 NUKON에서 침출반응에 의해 화학 적 부산물이 생성되어 수두손실을 서서히 증가시킨다는 것을 그림 4에서 확인할 수 있다. 따라서 여과기에서 수 두손실은 재순환수에 노출된 화학적 영향을 주는 물질의 양에 크게 의존하여 ECCS의 재순환운전 초기에 금속의 부식에 기인하여 생성된 화학적부산물에 의해 수두손실 이 급격히 증가하고 금속에 부동피막이 형성된 이후에는 침출반응에 기인하여 발생된 화학적부산물이 수두손실에 영향을 줌을 알 수 있다.

\section{5. 결론}

고리 1호기에 대해 LOCA이후 환경에서 원자로건물집 수조 여과기의 화학적 영향을 고려하여 30 일 동안 수두 손실 변화를 평가하였다. 시험결과 단기살수조건은 0.26 $\mathrm{kPa}$ 의 수두손실을 장기살수조건은 $3.6 \mathrm{kPa}$ 의 수두손실을 보였다. 시험결과는 수두손실이 살수조건에 따라 노출된 화학적 영향을 주는 물질의 양에 크게 의존함을 나타내 었다. 시험종료후 수거된 침전물의 XRD 분석은 대부분 의 침전물이 인산화합물임을 보였다. 용액에 용해된 화학 종과 수두손실의 변화를 비교한 결과, 화학적 영향을 주 는 물질 중에서 $\mathrm{Al}$ 과 $\mathrm{Zn}$ 성분은 시험초기에 부동피막이 형성되기 전까지 높은 수두손실 증가율의 원인이 됨을 보였다. 부동피막이 형성된 이후에 수두손실 증가율은 감 소하지만 지속적으로 수두손실이 증가하는 현상은 NUKON 및 콘크리트에서 침출반응에 의해 발생하는 $\mathrm{Si}$, $\mathrm{Mg}$, 및 $\mathrm{Ca}$ 이 침전물을 형성하는 반응에 기인한 것으로 판단된다.

따라서 원자로건물집수조 여과기에서의 수두손실 증 가는 화학적 영향을 주는 알루미늄 및 아연의 부동피막 형성률에 크게 의존할 것이다. 부동피막이 형성된 이후에 도 침출반응에 의해 발생하는 이온들의 재침전에 따라 수두손실은 지속적으로 증가하지만 알루미늄 및 아연의 부식에 의한 영향보다 작을 것이다. 화학적 영향에 의한 수두손실 증가를 억제하기 위해서는 LOCA이후 부동피 
막 형성시간을 단축시키고 원자로건물에서 알루미늄과 아연과 같은 화학적 영향을 주는 물질이 살수 및 재순환 수에 노출되는 양을 줄일 필요가 있다.

\section{참고문헌}

[1] D.V. Rao, et al., "Knowledge Base for the Effect of Debris on Pressurized Water Reactor Emergency Core Cooling Sump Performance", NUREG/CR-6808, USNRC, 2003.

[2] NRC Generic Letter 2004-02, "Potential Impact of Debris Blockage on Emergency Recirculation during Design Basis Accidents at Pressurized-Water Reactor", September 13, 2004

[3] J. Dallman, et al., "Integrated chemical effects test project: Consolidated Data Report", NUREG/CR-6914. U.S. Nuclear Regulatory Commission, December 2006

[4] 구휘권, 등, "LOCA이후 환경에서 원자로건물집수조 여과기에서 수두손실에 대한 화학적 영향”, 한국산학 기술학회지, Vol. 10, No. 11, 2009.

[5] 한국수력원자력(주), "고리 1호기 비상노심냉각계통 재순환집수조 성능평가 최종보고서, TR.운영해 석.S2007.01, 2006.

[6] Korean Standards Association, "Testing Method of Compressive Strength of Hydraulic Cement Mortar", KSL 5105, 2007.

\section{구 희 권(Hee Kwon $\mathrm{Ku})$}

[준회원]

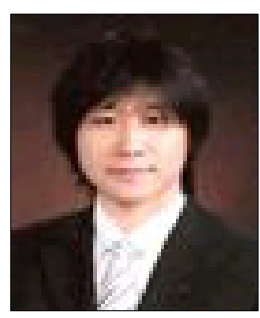

- 2008년 3월 현재 : 순천향대 학교 화학-환경공학과(석사과정)

<관심분야>

수질관리, 수처리
정 범 영(Bum Young Jung)

[준회원]

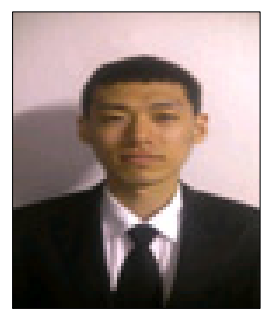

- 2009년 3월 현재 : 순천향대 학교 화학-환경공학과(석사과정)

<관심분야>

수질관리, 수처리

\section{홍 광(Kwang Hong)}

[준회원]

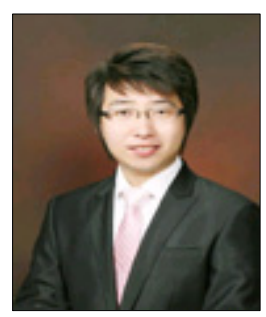

- 2009년 3월 현재 : 순천향대 학교 화학-환경공학과(석사과정)

<관심분야>

수질관리, 수처리

정 은 선(Eun Sun Jeong)

[준회원]

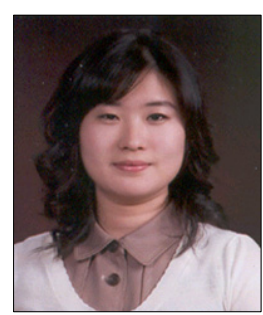

- 2008년 3월 현재 : 순천향대 학교 화학-환경공학과(석사과정)

<관심분야>

수질관리, 수처리 
정 현 준(Hyun Jun Jung)

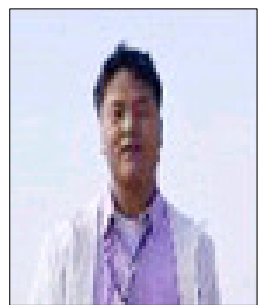

<관심분야>

수질관리, 수처리

- 2007년 3월 현재 : 순천향대 학교 화학-환경공학과(공학석사)

박 병 기(Byung Gi Park)

[정회원]

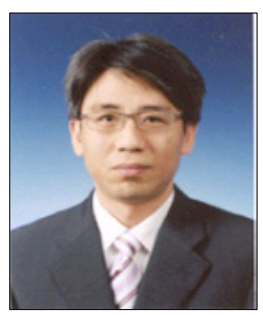

- 1993년 2월 : 서울대학교 원자핵 공학과 (공학석사)

- 1999년 2월 : 서울대학교 원자핵 공학과 (공학박사)

- 2007년 3월 현재 : 순천향대 학교 교수

<관심분야>

수질관리, 원자력, 용융염

\section{이 인 형(In Hyoung Rhee)}

[정회원]

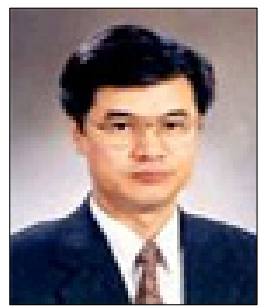

- 1990년 2월 : Cornell University 토목환경공학 (공학석사)

- 1996년 2월 : Carnegie Mellon University 토목환경공학 (공학박 사)

- 1998년 3월 현재 : 순천향대 학교 교수

<관심분야>

수질관리, 수처리, 계면화학

\section{박 종 운(Jong Woon Park)}

[정회원]

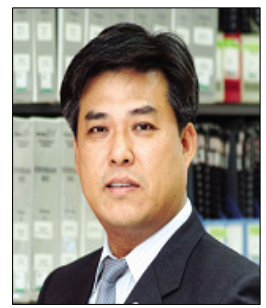

- 1989년 2월 : KAIST 원자력 및 양자공학과 (공학석사)

- 1993년 2월 : KAIST 원자력 및 양자공학과 (공학박사)

- 1993년 3월 현재 : 한국수력 원자력(주) 책임연구원

<관심분야>

원자력 